\title{
Research on River Chiefs System in China: Effect Evaluation, Defects and Future Prospects
}

\author{
Shaogang Liao, Jiayi Zhong, Xueman Fu \\ School of Public Finance and Public Administration, Jiangxi University of Finance and Economics, Nanchang, China \\ Email address: \\ liaoshaogang@163.com (Shaogang Liao)
}

\section{To cite this article:}

Shaogang Liao, Jiayi Zhong, Xueman Fu. Research on River Chiefs System in China: Effect Evaluation, Defects and Future Prospects. International Journal of Natural Resource Ecology and Management. Vol. 3, No. 2, 2018, pp. 24-31. doi: 10.11648/j.ijnrem.20180302.11

Received: May 16, 2018; Accepted: June 8, 2018; Published: July 7, 2018

\begin{abstract}
It is well known that water resources are one of the most important conditions for a country to develop healthily and sustainably. Since the outbreak of blue algae event in 2007, Wuxi city has put forward the "River Chiefs System" for all kinds of water resources pollution, have achieved considerable results. There are many problems in the protection and management of water resources in China. Based on the analysis of the basic situation of several typical abundant water resources in China and the current water resources management policy, this paper evaluates the effect of implementing "River Chiefs System" and puts forward some optimized countermeasures to improve the management and protection of river and lake and promote the construction of water ecological civilization in China.
\end{abstract}

Keywords: China, "River Chiefs System", Implementation Effect, Future Prospects

\section{Introduction}

In 2007, after the outbreak of blue algae in Taihu Lake and the water supply crisis, Wuxi in the year 8 month began the river basin governance mechanism of the innovation attempt-River Chiefs System, that is, within the jurisdiction of the river in the river-by-article clearly from all levels of party and government leaders as the River Chiefs, responsible for the implementation of the river Regulation and management measures, To realize the continuous improvement of river water quality and water environment, and to guarantee and promote sustainable development of economy and society.

At the end of 2016, the central government's comprehensive reform leadership group, the General Office of the CPC Central Committee and the State Council have adopted and issued the "views on the overall implementation of the "River Chiefs System", it pointed out: "The overall implementation of the "River Chiefs System" is to implement the green development concept It is an effective measure to solve the problem of complex water in China and to maintain the healthy life of the river and lake, and it is the system innovation of perfecting water management system and guaranteeing national water safety." Required that River Chiefs System should be established throughout the country by the end of the year 2018, than to promote the protection of river and lake system and the overall improvement of water ecological environment, to guarantee the sustainable use of river and Lake function, and to maintain healthy life of river and lake. This policy marks the "River Chiefs System" has been responding to the water crisis from the emergency measures, rising to the national will.

\section{Literature Review of the "River Chiefs System"}

"River Chiefs System" as a local initiative and bottom-up, throughout the country to promote the specific institutional arrangements, its basic practice is: all levels of the party and government mainly responsible for the respective areas of the "River Chiefs" of the river, and adopts the rigorous appraisal appraisal mechanism to give rewards and punishments under the guidance of water pollution prevention and control plan, through the target thinning, the gradual transfer carries on the aquatic environment management.

(1) Research on the Policy and Regulations of "River Chiefs System"

On the one hand "River Chiefs System" is centralized unification of water environment administration power, on the other hand, it is the strict accountability of administrative 
power of water environment management, which has important environmental law significance. He Qin (2011) from the perspective of environmental protection law, "River Chiefs System", to explore the legal basis of "River Chiefs System", analyze its legal short board, and on the basis of the development of "River Chiefs System", put forward to perfect the environment fin of "River Chiefs System", including establishing the unified chiefs-term mechanism, perfecting the planning and evaluation mechanism, and the introduction of a system of public participation and supervision. Qian Yu (2015) through a study of "River Chiefs", analyze its legal status and legal basis, find out what's wrong with it, The problem of passivity and the rule of man by the "River Chiefs". Wang Yong (2015) believes that through the introduction of procedural rationality and the promotion of the quality of the rule of law, government-led and public participation in the effective connection, the rule of law and internalization of target accountability, and the transformation of structural optimization and legal relations to balance the imperfect of "River Chiefs System", there are contradictions and problems such as rule of law and ruling by man, centralization and democracy, temporary and permanently, unification and pluralism.

(2) Comments on the Advantage and Inferiority of "River Chiefs System"

At present, the academic circles hold different viewpoints on the continuous implementation of the "River Chiefs System". Wang Shuming and Cai Mengmeng (2011) consider itself a system flaw: cannot eradicate the question of Entrustment and agent; Lack of transparent oversight mechanisms; Prone to collusion in interests; ignoring social forces; Administrative accountability is difficult to implement. Liu Zianqui (2011) from the perspective of environmental law, that through the refinement of administrative responsibilities, the responsibility to the individual, so as to avoid the water in the process of wrangling, shifting, greatly improve the efficiency of sewage treatment and implementation. Shen Manhong (2018) analyzes the institutional performance of "River Chiefs System", and considers that the environmental performance of "River Chiefs System" is a single positive, and both economic performance and social performance are dual. Under the background of water crisis and water system crisis, even if there are negative effects of system, the system is worth affirming if the positive effect is greater than the negative effect.

(3) The Direction and Path Choice of "River Chiefs System"

Liu Hongzhi, Liu Xianchun, etc. (2016) analysis and summary of the practice experience since the establishment of "River Chiefs System" has pointed out that the system also has some problems, such as weak overall coordination of watershed management and insufficient capital investment. First of all, Zhu Mei (2017) from the environmental management, to reform the top design angle, in the legal development, assessment mechanism and public participation in three aspects to solve the responsibilities of non-statutory, power and power is not equal, coordination mechanism failure, assessment of the lack of science and other problems. If there is a lack of public participation in the river system, $\mathrm{Li}$ Yunsheng (2009) believes that the most important thing is to protect citizens' environmental rights to the fullest extent. If the implementation of environmental protection laws and regulations, project approval and other government affairs open system, through the timing, timely release of relevant project progress and environmental quality data, exposure to environmental violations to improve the government website. As for the "River Chiefs System" of the rule of man abuses, most scholars. Finally, the government rely on system construction. Liu Fangxiong, He Tingying (2016), promote the rule of law construction of "River Chiefs", the first is to perfect legislation to promote the institutionalization of the "River Chiefs", two is the democratic consultation to promote "River Chiefs System" operation of the scientific, benefit equalization to promote the public participation of "River Chiefs System". Second, can also be based on other domestic and foreign water pollution control experience to enrich the "River Chiefs System" of supporting mechanisms. such as Nie He, Shao Meiling (2009) that, in view of the accumulation of water environment problems, hysteresis and other characteristics, should establish a continuous and effective tracking supervision system, officials in the Office of Environmental Responsibility will still be tracked, regardless of their movements, regardless of the chiefs of time interval, The responsibility of officials is never tolerated.

At present, the academic circles discuss the perfect direction of "River Chiefs System" from different angles or clarify its route choice, overall, the results are worth affirming, but most of the countermeasures are still more abstract, only to analyze the advantages and disadvantages of the "River Chiefs System" itself, the development trend and the need to implement "River Chiefs System", or only according to a certain area of case analysis. In addition, in how to solve the shortcomings of the rule of man, how to ensure the examination and accountability of scientific, feasibility, and so on, many scholars have invariably thought to rely on legal construction, the "River Chiefs System" into the rule of law track. Indeed, the current "River Chiefs System" has a certain realistic legal basis, and its own existence is constantly institutionalized by the trend of law, which is the modernization of the rule of law with the requirements of the State. But the author thinks pursue the construction of the legal system of "River Chiefs System" will lead the discount or total loss of its flexibility and efficiency. Therefore, the path of relying solely on the legal system is impractical and outdated, and the development and perfection of the "River Chiefs System" should be constantly explored.

Through the collation the above literature, the research of "River Chiefs System" in China is still in the initial stage, the results mainly focus on the absence and irregularity in the existence and development of the "River Chiefs System", in solving the problems of the rule of man and the examination and accountability, most scholars focus on the realistic goal of perfecting the legal system and promoting the rule of law. In addition, some scholars discuss the "River Chiefs System" from 
the perspective of the trans-department cooperative governance of the river basin. But there is not much research on the effect of "River Chiefs System". Therefore, it is beneficial to combine theory with practice by investigating the effect of the "River Chiefs System" in some provinces of China.

\section{Construction of China "River Chiefs System" Implementation Effect Evaluation System}

The effect evaluation system of "River Chiefs System" can be composed of four parts, such as pollution reduction, water environment remediation, water resources management and water function promotion. Among them, the water pollution emission reduction is indicated by the waste water discharge situation and the pollutant discharge in the waste water, which is indicated by the regional drainage capacity and sewage treatment capacity; Water resources management is represented by water resource utilization efficiency and regional water supply capacity; water function promotion by ecological function and economic function. See table 1 for specific indicators.

Table 1. Implementation evaluation system of River Chiefs system.

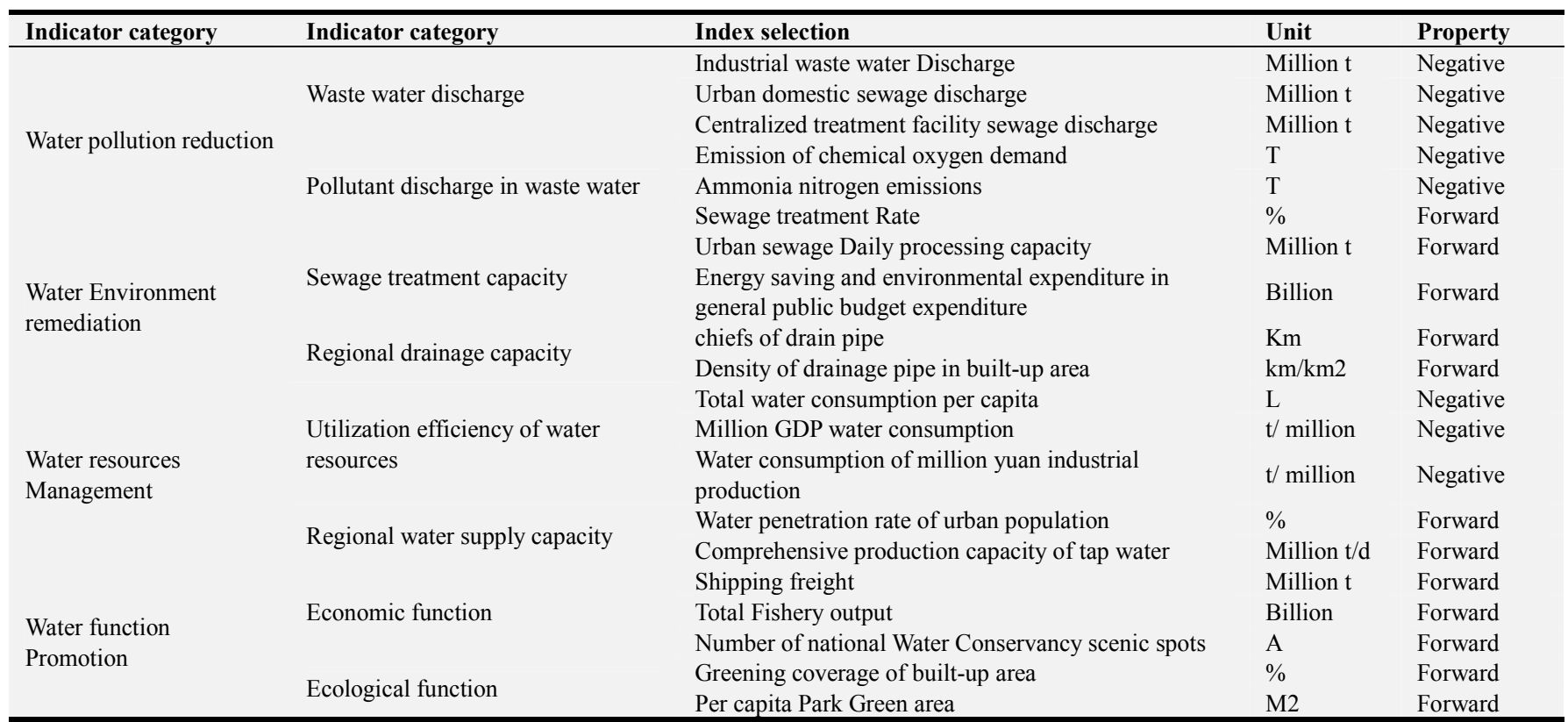

Table 2. Eevaluation and growth of River Chiefs system in Jiangsu Province from 2006 to 2015.

\begin{tabular}{|c|c|c|c|c|c|c|c|c|c|c|}
\hline Year & 2006 & 2007 & 2008 & 2009 & 2010 & 2011 & 2012 & 2013 & 2014 & 2015 \\
\hline Score & 0.309 & 0.430 & 0.508 & 0.524 & 0.596 & 0.498 & 0.553 & 0.652 & 0.735 & 0.758 \\
\hline Growth rate $(\%)$ & - & 39.31 & 18.14 & 3.03 & 13.84 & -16.43 & 10.96 & 17.82 & 12.76 & 3.18 \\
\hline
\end{tabular}

\section{Comparison of the Implementation Effect of "River Chiefs System" in Some Provinces of China}

(1) Effect of "River Chiefs System" in Jiangsu Province Jiangsu is the first to popularize the "River Chiefs System" in China, the municipal government has issued a corresponding policy to promote the implementation of "River Chiefs System".

As can be seen from the table 2, from 2006 year to 2015 year of Jiangsu Province, the implementation of the "River Chiefs System" has been effective, water ecological civilization construction level is rising, only 2010-2011 the year appears negative growth. At the period of "the Eleventh Five-year Plan", that is, the 2006-2010, Jiangsu Province "River Chiefs System" to promote the construction of water ecological civilization has made great contributions. The 2007 year is the first year of the concept of "River Chiefs System", Wuxi promote the "River Chiefs system" in Taihu basin, which led to the surrounding cities have followed, the introduction of relevant policies to promote the "River Chiefs System", and promote the construction of water ecological civilization. The implementation of "River Chiefs System" is not obvious in 2010-2012, Jiangsu province water Ecological civilization construction results fluctuate. This is because the system is a kind of imitation and spontaneous behavior and lack of high-level co-ordination. for several years, the "River Chiefs" lose their enthusiasm and enter into a managed fatigue period. In addition, the responsibilities of the river is not very clear the beginning of "River Chiefs System", leading to the construction of water ecological civilization stagnation or even retreat. 2013-2015 year, Jiangsu Province water ecological civilization construction and the implementation of "River Chiefs System" has entered another rapid growth stage 
due to Ministry of Water Resources issued "on speeding up the construction of aquatic ecological civilization" in january 2013, the idea of water ecological civilization construction of the basic principles, objectives and main work, for the implementation of "River Chiefs System" put forward requirements, pointed out the direction. The three stages of "River Chiefs System" in Jiangsu Province are closely related the design and the promotion of "River Chiefs System".

(2) The Present Situation of Implementing "River Chiefs System" in Jiangxi Province

After the implementation of the "River Chiefs System", the major achievements have the following points: first, the mastered the basic situation of the river and Lake. In order to further clarify the situation and study the countermeasures, many regional organizations carried out a large scale of the river channel condition investigation. Second, promote the strengthening of the regulation. Through the coordination and supervision of the "River Chiefs", the comprehensive regulation of the river and lake has been further intensified, and the establishment of the river-chiefs system has formed the mechanism of River comprehensive regulation, and achieved more obvious results. Third, promote the implementation of long-term management. In the region where the "River Chiefs System" is implemented, ensure the effective measures of long term, the long-term management funds, the strengthening of long-term management team, the strengthening of the administrative supervision and the monitoring of the society. Establishing the relevant administrative supervision mechanism and the social supervising mechanism. Four is to promote the formation of the combination of river. The comprehensive regulation and management of river courses involve many departments, which need cooperation and co-operation from many departments. After the implementing of "River Chiefs System", the party and government leaders can better solve problems between the departments, and make concerted efforts in strengthening the regulation and management of river courses. Finally is to promote the improvement of the water environment. By the end of 2017, Jiangxi Province has stabilized the rate of surface water quality in $80 \%$, the main urban drinking water quality compliance rate $100 \%$, the pollution of river and lake has also been some improvement.

(3) The Effect of "River Chiefs System" in Zhejiang Province

In 2008, Huzhou City Changxing County issued a document for the first trial of the "River Chiefs System" to establish the system. Subsequently, Jiaxing, Wenzhou, Jinhua and other cities of the system documents have been launched.

According to the environmental status Bulletin of Zhejiang Province in the 2006-2017, during 2005-2011, the surface water quality changes in Zhejiang show a fluctuating and unstable trajectory, after the implementation of the "River Chiefs System" in 2011-2016, the percent of I class water and II class water (represents high quality water) rise stably, represents the inferior water: $\mathrm{V}$ class water, proportion stable decline, see table 3. Visible from table 3, the I class water quality is higher than the $10.9 \%$ from $6.8 \%$ of year to 2016 year; II the proportion of water from $25.8 \%$ in year to $38.5 \%$ 2016 year; The proportion of $\mathrm{V}$ water to the $4.1 \%$ of 2016 year from $6.8 \%$ of year; The inferior $\mathrm{V}$ water ratio drops from $18.6 \%$ of the year to $2.7 \% 2016$ year. High quality water accounted for more and more, inferior water accounted for less and less. This is the important characteristic that water environment quality improves obviously. Especially after the implementation of "River Chiefs System", surface water quality improvement is more remarkable.

Table 3. The rate of standard-attainment of emphasis waterfunction zones for Taihu between 2007 to 2016.

\begin{tabular}{|c|c|c|c|c|c|c|c|c|c|c|}
\hline Year & 2007 & 2008 & 2009 & 2010 & 2011 & 2012 & 2013 & 2014 & 2015 & 2016 \\
\hline Rate (\%) & 22.5 & 32 & 29.7 & 35 & 32 & 40.6 & 33.7 & 38.7 & 42.6 & 56.5 \\
\hline
\end{tabular}

(4) A New Chapter in Water Conservancy in Guizhou Province

In accordance with the requirements of the "River Chiefs System", Guizhou Province has been the pollution of the river basin within the time limit for the management of environmental pollution tasks, and actively promote the heavy pollution industry renovation and environmental protection facilities. such as: Maotai company completed the table boiler coal to change gas, daily reduce the discharge of waste water 1500 ton; 4 main phosphate mining enterprises in the Wenan River basin completed the task of mine waste water treatment. Through the implementation of "River Chiefs System", Guizhou province increase capital investment efforts to actively promote pollution. In "the 12 Five-year Plan" period, only San Cha river, the cumulative investment in pollution control funds 14 million. The "" area and upstream area have 157 Pollution Abatement projects, at the end of 2015 has completed 144 projects, complete investment as much as 26billion, the rate of project completion is $91.7 \%$. Fully meet the requirements of the National Planning Assessment Project Completion rate: $80 \%$.

(5) Evaluation of the Effect about the "River Chiefs System" in China

First, the chiefs executive Accountability system has been established. The "River Chiefs System" captures the "keywords" of the head of the local government as the responsible person. Taking the "River Chiefs System" birthplace of Wuxi as an example, the paper introduces the appraisal system of the effect evaluation, in addition to the economic income linkage, it also takes a series of administrative punishment measures, and gives the corresponding punishment to the leaders who have poor performance in annual examination. It can be considered that the essence of the system of responsibility mechanism is the "responsibility system" of the leading cadres.

Second, solve the "water treatment of Kowloon" dilemma. In the year of 2013, Zhejiang province established the "Five Water Governance" system management path, strengthened 
the cooperation of the wading department. Led by the Environmental Protection Department, environmental protection departments Misting pollution water, water conservancy departments Misting flood control water, water supply, housing construction department Misting drainage water, grasping water-saving, in the provincial leadership group Office of the Head of the Ministry of Management, overall planning, division of work, with less effort. In the same year, Jiangsu Province formed a level of government, water conservancy, environmental protection and marine Fisheries and other departments of the Lake Management and Protection Joint Meeting system, and further integration of various regions, departments involved in Lake management functions, change for the united management of the lake, the province's lakes have established joint Meeting working mechanism. The establishment of the department cooperation mechanism has relieved the past function division, not only can grasp the law of water treatment scientifically, but also can concentrate on the lower cost to achieve the goal of the flood control.

\section{Defects in the Implementation of "River Chiefs System"}

Watershed governance has been a difficult problem for the government since ancient times, because this work involves a number of stakeholders, so the academic and political parties advocate cooperative governance, some scholars believe that the river is actually a water environmental responsibility system, can also be said to be a "principal-agent" form. Although the "River Chiefs System" has obtained the remarkable effect in the practice, but it still belongs to the rule of man in essence, not the law. Its implementation and practical effect depends on whether the local party and government leaders pay attention to the water environmental protection, whether they are willing to be "River Chiefs", rather than relying on the legal provisions. Although the "River Chiefs System" is not a perfect system, it is still a comprehensive promotion, full of Chinese characteristics, the formation of Chinese unique experience in watershed management. The following are analyzed in several ways:

(1) There are Some Problems with the" River Chief System" Itself

As mentioned above, "River Chiefs System" cannot get rid of "entrust-agent" This problem, "principal-agent" refers to any organization containing two or more than two people, as chiefs as one's action is based on another action, it proves that there is a "principal-agent" relationship. To see everyone in this relationship as an "economic man", they will pursue the maximization of their personal interests at work, and the agent will not always act according to the will of the client, or even sacrifice the interests of the agent. The same in the "River Chiefs System" implementation process, there is such a relationship, the citizen is a broad sense of the client, the Government is the main agent of environmental governance. Because government officials are rational "economic people", they will take opportunistic actions in defiance of their clients' wishes for higher salaries, allowances and other non-material remuneration. Citizens and government information is always asymmetrical, so citizens are always the victims of this cost.

(2) Lack of Scientific Approach to Water Environment Assessment

The assessment of the local "River Chiefs" is mainly based on the result and the aim of improving water quality. For example, Wuxi a district requires each "river" to pay the 3000 deposit per channel, and turned over to the District "River Chiefs System" Management margin Special account, with "water quality improvement, water quality maintenance status, water quality deterioration" and other comprehensive index as evaluation criteria, set three types of rewards and punishments:"The full return of the security deposit and in accordance with the margin of payment of the amount of reward, the full return of security and full deduction of margin". For the poor performance of the annual assessment of the leadership, the mathod have the following point:talk to them, inform the criticism, ordered inspection, obliging public apology, until the adjustment of the job, ordered resignation, dismissal and other corresponding punishment. However, the improvement of water quality is not an overnight measure, and only the measurement of the water quality in the short term may lead to a reverse effect or even dampen the enthusiasm of the grassroots river. Therefore, the assessment should consider the natural endowment, economic and social conditions and many other differences.

(3) The Duties of "River Chiefs" Without supported by law, and Responsibilities are Not Equal.

Whether the river is ruled by man or by law is the focus of controversy among scholars from all walks of life. At present, only a few areas such as Kunming to the local laws and regulations, Wuxi, government orders to give the "River Chiefs" responsibility, but how to implement still have the legal means vacancy problem. Most of the areas are mainly driven by executive order and forced force, which makes this work is considered as a sport work, with temporary, surprise characteristics, many "River Chiefs" lack of intrinsic lasting power. At the county level and above the party leaders as chiefs as the river is a minority, most of the river is deputy leadership, or departments, streets and township leaders, and even the village committee cadres, lack of necessary means of work and coordination of propulsion capacity. Especially in personnel management, funds allocation and other key links do not master, often powerless.

(4) "River Chiefs" ignores the power of the masses

In discharging its functions, the Government should intervene as little as possible, and should fully mobilize the enthusiasm of the public. As for the protection of water resources, the Government should act as the "night Watchman", respect the citizen of the enterprises and factories on the environment, and guarantee the citizens' right to know, supervise and Sue. And the "River Chiefs System" is a very obvious flaw is that it is only the government's internal personnel to the water environmental protection mobilization, did not really ignore the mobilization of the community 
around the public enthusiasm.

The optimization strategy for this defect water resources environmental protection is a huge social work, only rely on the ability of government personnel can not be effectively implemented, living in society, everyone has more or less damage to the water environment, so everyone has the responsibility for water environmental protection to make their own contribution. Therefore, the government needs to educate citizens and create a citizen with excellent environmental protection awareness. On the other hand, there is no clear legal provision to support the accountability of the "River Chiefs", resulting in a lot of uncertainty in the implementation process, so that in the case of accountability, all processes and results should be made public.

\section{The Prospects for the Future of China to Promote "River Chiefs System"}

Hayek believed that good system, benefit sharing rules and principles, can effectively guide people to use wisdom, so that can effectively guide the realization of social goals. For the future development of China "River Chiefs System", the author has the following prospects:

(1) Improve the "Principal-Agent" System Defects, Improve the Relevant Supporting Policies

Appropriate incentives for agents (Governments) can also improve the supervision and punishment of agent opportunism, and the government should maintain a balance between public and government officials and the environment, and should change the concept of governance, rather than the pursuit of economic benefits. This can make "River Chiefs System" effect maximization.

It is generally believed that the key to the moral hazard problem is to design an optimal incentive contract so that the agent chooses the action that the client wants, so that the agent can maximize the utility of the client while pursuing the maximization of his own interests. An easy way to solve the problem of "principal-agent" is to strengthen the supervision and encouragement to the agent and restrain the agent's opportunism motive. The new institutional economics holds that for the hierarchy of the problems, the key of efficiency is whether the government can design a set of effective supervision incentive contract to induce each agent's behavior, including revealing his personal information, choosing higher level of effort and so on, so as to limit the agent's behavior to the client's benefit, and reach "Incentive Compatibility", so that the agent in pursuit of their own utility maximization at the same time, to achieve the maximum effectiveness of the client. The perfection of "River Chiefs System" depends only on the administrative accountability system, in addition to the administrative system internal supervision, legal supervision, but also need to be in the Government and other governing bodies outside the introduction of Third-party supervision mechanism, it must be combined with the general public groups to establish a strong monitoring mechanism, set a series of hard indicators, and fully guarantee the implementation. On this basis, the relevant person responsible for the pollution reduction targets should take administrative punishment measures.

"River Chiefs System" not only raises the importance to water problem, but also strengthens the responsibility of water management of local party and government officials. Such a perfect system of formation, need to establish corresponding policies and measures. should be in accordance with the construction of responsibility clear, the requirement of coordinated, orderly, strict supervision and protection mechanism of river and lake management, according to the natural and social functions of a single river and regional river with "River Chiefs System", clarifying the responsibility objectives and related requirements of the "River Chiefs" and the related management departments, so that their responsibilities and the tasks of governance objectives are matched. To clarify those responsible, the rights and obligations of participants, beneficiaries and supervisors, clarifying the content of the responsibility of the person concerned, including leadership, direct, indirect and other responsibilities, and how the relationship between the river and the relevant departments, between the regular deputy and the different river levels is determined., Avoid shifting when responsibility is not clear and authority is unclear. All regions should adapt to local conditions and constantly improve the implementation of the relevant policies of "River Chiefs System".

(2) Scientifically Establish Assessment Mechanism, Solve the Problem of Fairness and Justice, and Better Implement the System of Liability Investigation of Ecological Environmental Damage

The "views on the overall implementation of the "River Chiefs System" proposed by the county level and above "river" responsible for the organization of the corresponding river and lake under the "River Chiefs" assessment, directly locked assessment object. But the government should also pay attention to improve the scientific rationality of accountability, therefore, the "views on the overall implementation of the "River Chiefs System" to carry out the evaluation of differentiated performance assessment, incentive to accountability, but also put forward the implementation of the responsibility for the life of ecological environmental damage system. This requires all levels of party and government leadership to co-ordinate economic, social development and environmental protection, in the river and lake development and construction work must be synchronized or even give priority to the implementation of river and lake protection policy measures, or once the damage will be responsible for life. New chiefs system assessment to fully summarize the experience and lessons, grasp the scale, and conscientiously implement good responsibility, fair and reasonable.

(3) In Order to Provide Norms and Support to the "River Chiefs System", the Relevant Laws and Regulations should be Improved

For the "River Chiefs System" to The current laws and regulations do not make a clear specification for the implementation of "River Chiefs System". The 
comprehensive implementation of "River Chiefs System", involving many fields, institutions, groups, need the government, enterprises, society and individual exerting force, must establish and improve the overall implementation of the "River Chiefs System" of laws and regulations, for the implementation of "River Chiefs System" to provide norms and support. In accordance with the relevant requirements according to law, the regulation of "River Chiefs System" of relevant content into laws and regulations and related regulations, and in different laws and regulations to maintain a high degree of consistency, clear and comprehensive implementation of the "River Chiefs System" of the relevant requirements, clear "River Chiefs" main responsibilities and related systems, standardize the "River Chiefs" naming, the main requirements and related procedures, Standardize "River Chiefs System" to govern river, the key link of water control and target task, standardize "River Chiefs System" related responsible person's supervision and examination.

(4) Increase the Participation of the Public and Third Parties to Form a New Pattern of Universal Participation in Water Harnessing

The public participation can not be separated from the water resources protection, water pollution prevention and control, aquatic environment treatment and water ecological restoration, and it can also supervise the local government and relevant departments by taking part in the maintenance of their own wading, river-related rights and interests, as well as supervising the implementation of the corresponding duties., Therefore, it is necessary to establish an open and transparent public participation mechanism so as to exert the positive role of "River Chiefs System". The government should strengthen the propaganda and guidance, strengthen the consciousness of the society and the public to protect the river and lake, encourage the public to participate actively in the implementation of the "River Chiefs System", and constantly improve the supervision and examination mechanism for the implementation of "River Chiefs System".

The third party organization is the bridge which links the government and the people, can make up the government ability insufficiency, can let the public become the third eye which supervises the river Regulation, becomes the social common rule one important strength. Therefore, the "River Chiefs System" should pay more attention to the power of the third party institutions, in order to make up for the government's lack of water resources protection, and finally form the government-enterprise-public such a solid pattern of governance.

\section{Conclusion}

The implementation of the "River Chiefs System" represents the successful practice of the Chinese government to the environmental governance system innovation, it has clarified the responsibility of water pollution management, and ended the situation of "Kowloon Flood Control" in the past. It helps to play the role of government organization and leadership, strengthen the implementation of responsibility, coordinate various departments, promote the whole society to control water pollution, improve the water environment, scientifically and rationally protect the utilization of water resources, form the chiefs-term protection and management mechanism, protect river and Lake Health, promote China's ecological civilization construction and economic and social sustainable and rapid and healthy development. However, the "River Chiefs System" can not be regarded as a chiefs-term implementation of the environmental management system, should be continuously improved in the development. Due to asymmetric information, the principal-agent problem is unavoidable, meanwhile, the river system ignores the social forces and lacks the effective supervision power. Therefore, improving the consciousness of the local government leading cadres to implement the scientific concept of development, and effectively transforming the economic subject-oriented government into a service-oriented government, forming a working force for the whole society to participate in environmental management, and establishing a set of water control system with Chinese characteristics, the development of water treatment in china will have a healthy development.

To overcome the above problems through the research, it is beneficial to establish a comprehensive, coordinated and sustainable scientific development view, provide theoretical and decision-making reference for the construction of "River Chiefs System"; It is beneficial to explore schemes for the smooth advancement of water management; It is beneficial to build "beautiful China", provides new inspiration for the construction of "River Chiefs System" in the whole country. However, there are still some areas should be improved in this study. Firstly, due to insufficient theoretical knowledge, the integrity of the relevant data collection level may be insufficient. Secondly, the object of investigation is the large group of government officials related to the work of "River Chiefs System" in China, which may not be comprehensive in the process of collecting data, and there will be errors. In the field investigation, according to the different status of the responsible person in each region, the analysis has certain difficulty and so on. Therefore, it is necessary to further strengthen the study of theoretical knowledge and the collection of relevant materials in the process of writing the paper. At the same time, the writer should pay attention to integrating theory with practice, analyze and solve problems in a scientific and rigorous manner.

\section{References}

[1] Yu Yizhen. The dilemma of "River Chiefs System" implementation and its countermeasures--effect and problem analysis of Hangzhou "River Chiefs System" Practice [J]. Journal of Lingnan Normal University, 2018, 39 (01): 62-66.

[2] Jang Mingdong, Sheng Xiaohai, Wang Yanying, Wang Lei. Study on effect evaluation and spatio-temporal difference of "River Chiefs System" in Jiangsu province [J/OL]. South-to-north water Diversion and Water Conservancy technology:1-11

[2018-04-19].http://kns.cnki.net/kcms/detail/13.1334.TV.2018 0309.1545.012.html. 
[3] He Qin. Thinking of the environmental law of the "River Chiefs System" [J]. Administration and Law, 2011, 20118): 78-82.

[4] Qian Yu. Discussion on the legal problems of "River Chiefs System" [J]. The rule of Law Expo, 2015 (2).

[5] Wang Yong. Paradox and solution of "River Chiefs System" in water environment control [J]. Western Law Review, 2015 (3): $1-9$.

[6] Wang Shuming, Cai Mengmeng. Comment on "River Chiefs System" based on the new institutional economics perspective [J]. Population, resources and environment of China, (9):8-13.

[7] Liu Zhanqui. Enlightenment of environmental law of Wuxi "River Chiefs System"[C]// China Law Society Environmental Resources Law Research Association annual Meeting.

[8] Shen Manhong. Institutional economics analysis of "River Chiefs System" [J]. Population, resources and environment in China, 2018, 28 (01):134-139.

[9] Liu Hongzhi, Liu Xianchun, Zhou Shipin. etc. Thoughts on deepening the system of "River Chiefs System"s [J]. Environmental protection, 2016, 44 (24):43-46.

[10] Zhu Mei. On the development practice and promotion of "River Chiefs System" [J]. Environmental protection, 2017 (Z1): 58-61.

[11] Li Yunsheng. From the river basin water pollution prevention and treatment see "River Chiefs System"[J]. Environmental Protection, 2009 (9): 24-25.

[12] Liu Fangxiong, He Tingying, Zhou Yuzhu. On the rule of law of "River Chiefs System" in the context of governance modernization [J]. Zhejiang journal, 2016 (6).

[13] Nie He, Shao Meiling. The improvement of environmental accountability system in China from the beneficial experience of "River Chiefs" [J]. Decision and information Shing, 2009 (one): 15-16.

[14] Liu Fang, Miao Wang. Study on the system model construction of the system elements of water ecological civilization Construction [J]. Population, resources and environment of China, 2016, 26:117-122.

[15] Liu Jutao, Wan Yiguo, Xu Xiaoyun, Wen Chunyun. The present situation and suggestions of "River Chiefs System" in Jiangxi province [J]. China Water Conservancy, 2016, (18): 51-53. [2017-09-21].

[16] Jiang Bin. Thoughts on the management system of "River Chiefs System" [J]. China Water Conservancy, 2016, (21):6-7. [2017-09-21].

[17] Zheng Yingying."River Chiefs" fulfil the laws of the implementation of the laws [N]. China Water Conservancy newspaper, 2017-10-19 (003).

[18] Dong Li. Guizhou Province:See how the "'River Chiefs System"'" to compose a new chapter of the Flood of water [J]. China environmental Monitoring, 2017 (Z1): 41-43.

[19] Ren Min."River Chiefs System":A sample study on cross-sectoral synergy of Chinese government basin governance [J]. Journal of Beijing Administration College, 2015, (03):25-31. [2017-09-21]. DOI:10.16365/j.cnki.11-4054/d.2015.03.004.

[20] Tao Changsheng."River Chiefs System": the hand of chiefs-term management of river and Lake [J]. China Water Conservancy, 2014 (a): 20-21.

[21] Hayek. The principle of free order (roll up) [M]. Beijing: Beijing Sanlian, 1997.

[22] Cheng Enfu, Hu Leming. New institutional economics [M]. BEIJING:economic Daily Press, 2005:118-119; 121-122. 